\title{
Review of The volcanosetting concept to discover the precious metal mineralization in Sunda Arc, Indonesia: a Approach Proposal for Mineral Exploration
}

\author{
Okki Verdiansyah $^{1}$, Hill Gendoet Hartono ${ }^{2}$, Oky Sugarbo ${ }^{3}$ \\ \{okki@itny.ac.id\} \\ Departement of Geological Engineering, Institut Teknologi Nasional Yogyakarta, Indonesia
}

\begin{abstract}
Indonesia have several worldclass mineralization deposits in its Tertiary magmatic belt. Many mineralization in Indonesia, especially in the Sunda belt, is generally formed in ancient volcanic systems and so far no research has been conducted on the direct relationship between the volcanism and mineralization systems present therein. Based on that, for the preliminary we need to review the concept of volcanism, the product and the presences of mineralization that's perhap can be used as a references for a more appropriate research rationale and leading accelerate the discovery of precious metals. The method we use is qualitative methods, from analysis of ocurences of mineralization, volcanomorphology, and concept of recent volcanoes as a limitation of the fact. Physiography of the Eastern Sunda shows two main complexes namely igneous rock formation and volcanoes on the south side, the characters of magmatism and volcanism in Tertiary, are likely similar to those formed today. The character of volcanism can be used as a reference pattern of eruption and formation of rocks on the surface, and possibly under the surface such as intrusion or batolite. The evolution of Quaternary volcanoes on the East Sunda path shows the evolution of morphology and magmatism that looks increasingly young to the west. All volcano complex are interpreted have one to two central facies, that creates a caldera system and following with few central volcanic eruptions as a single volcanic system. If the number of central eruptions increases then it is interpreted more active and complex the volcanic system and can be forming the great hydrothermal system. The simply volcanosetting concept, the volcanic facies, can be used to facilitate the discovery of deposits as a limitation of exploration area.
\end{abstract}

Keywords: volcano, mineralization, exploration, precious metal, Sunda Arch

\section{Introduction}

Indonesia have good mineralization potential as evidenced by the presence of world-class goldcopper deposits such as Grasberg in Papua and Batuhijau in Sumbawa island. The development of metal mineral exploration in Indonesia recently has increased in terms of technology and related science. Exploration of metallic minerals is usually carried out along magmatic pathways that are 
valued as potential, such as the Sunda-Banda belt, that has been proven by the presence of large copper and gold mines. (Maryono et al., 2018; Van Leeuwen, 2018).

The Sunda-Banda magmatism belt is one of the corridors where there are many prospects for gold-copper deposits of epithermal, porphyry, skarn, and sediment-hosted types (Hammarstrom et al., 2013). The development of gold mines in the Sunda-Banda Belt looks economical and has the potential to be proven by the presence of gold-silver and base metal mines such as Lebong Tanda (Bengkulu), Cikotok Complex (Banten), Pongkor (West Java), Batuhijau (Sumbawa) and the presence of gold mines such as Cibaliung (Banten, 2010), Waylinggo (Lampung), Martabe (Tapanuli), and Tumpangpitu (Banyuwangi).

So far, Exploration of metallic minerals still uses the lithodemics and lithostratigraphy concepts, which some places appear to be inappropriate to use. The development of volcanology has strengthened this time, as the discovery of the concept of mineral thermobarometry (Ten et al., 2011; Becerril et al., 2013), the improvement of the absolute dating for geochronology of volcanic rocks (Newhall et al., 2000; Zellmer et al., 2005; Harijoko et al., 2016), and strengthening the theory of volcanic evolution (Becerril et al., 2013; Nomikou et al., 2013). But all these things are generally done in the quarter volcanic system, and have not been done in the ancient volcanic system.

Mineralization in Indonesia, especially in the Sunda belt, is generally formed in ancient volcanic systems (Harjanto et al., 2006; Hartono, 2010; Verdiansyah dan Hartono, 2017) and so far no research has been conducted on the direct relationship between the volcanism and mineralization systems present therein. The volcanism concept has its own character on explain to lithology distribution problems, magma differentiation, superimposed volcano, volcanic evolution, especially the relationship of time and products.

In this paper, we will try to review the concept of volcanism, the product and the presences of mineralization that's perhap can be used as a references for a more appropriate research rationale and leading accelerate the discovery of precious metals.

\section{Methods}

The method we use is qualitative methods, from analysis of ocurences of mineralization, volcano-morphology, and concept of recent volcanoes as a limitation of the fact.

\section{Regional Geology of Eastern Sunda Arc}

In magmatic Sunda arc, especially in Java to Nusa Tenggara area, the presences of precious metal mineralization are associated with volcanic centers that's formed throughtout Oligocene Miocene and some to the Pleistocene subduction zone. These types of deposits include: porphyry copper-gold, high sulphidation epithermal, low sulphidation epithermal, gold-silver-barite-base metal, skarn, and sediment-hosted mineralization (Carlile \& Mitchell, 1994). The porphyry type in the Sunda magmatic belt is commonly associated with lithocap, epithermal and some skarn deposits (Hammarstrom et al., 2010).

Porphyry copper deposits in the Sunda-Banda belt are generally formed at Eocene - Pliocene ages, which is commonly associated with porphyry andesite rock bodies, porphyry dacite, and porphyry tonalite (Hammarstrom et al., 2013; Maryono et al., 2018). Some hypotheses say that 
calc-alkaline magmatism activity has decreased in the early Miocene, and followed by erosion and extensive formation of sedimentation. The mineralization present in the Sunda-Banda belt is generally associated with island arc (Carlile and Mitchell, 1994; Setijadji et al., 2006; Setijadji and Maryono, 2012; Maryono et al., 2018). In magmatic Sunda arcs, the placement of valuable metal deposits seems to be housed on volcanic centers such as Selogiri, Trenggalek and Salakan and some associations with windows of plio-pleistocene intrusions such as Tumpangpitu, Batuhijau, Elang and Hu'u (Gambar 1).

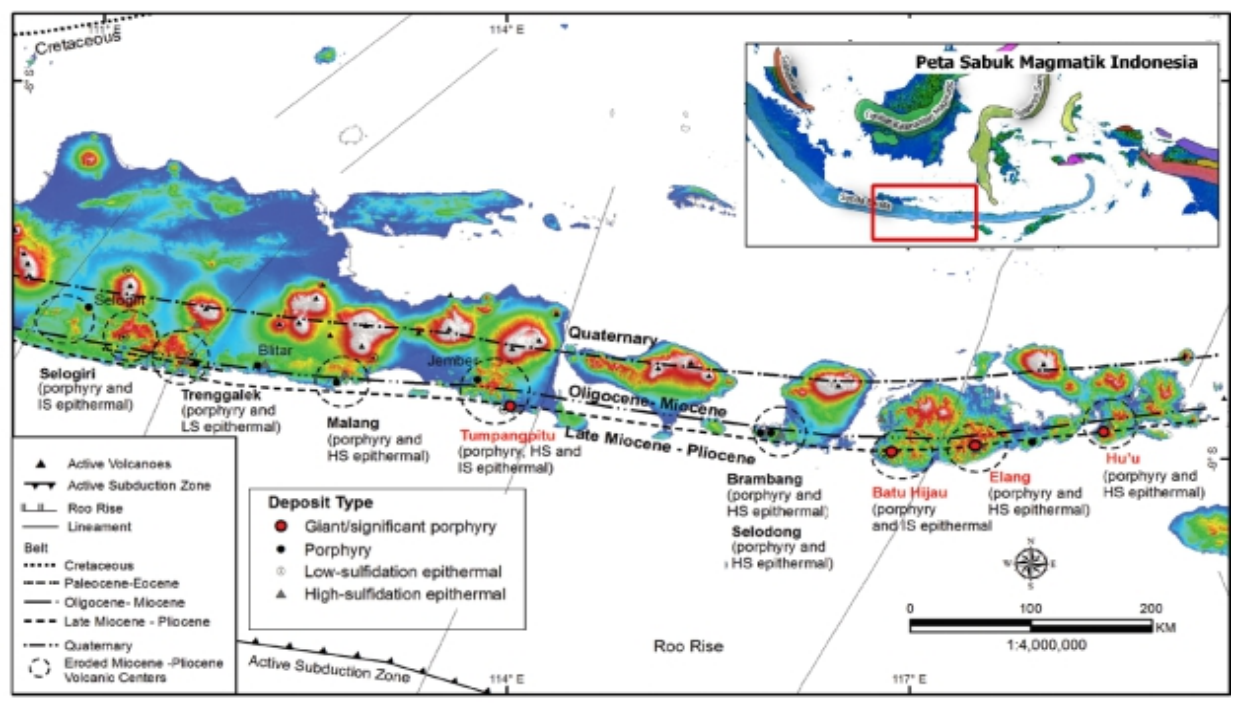

Fig. 1. Map of distribution of porphyry deposits and their associations in the Eastern Sunda Belt (Maryono et al., 2018).

The generation of the type of mineralization and age of volcanism or magmatism in Indonesia does not seem to have a direct relationship such as epithermal deposits which are not always younger than porphyry, and are not only found in volcanic centers (Setijadji dan Maryono, 2012), but it appears that the mineralization is formed intensively in the magmatic arc in which there are volcanic systems with various developments or evolution. The occurences of gold-copper mineralization in Java seems to vary from Miocene to Plio-Pleistocene, which seems to have an age range between initial intrusion (batolite) to mineralization of around 5-10 Million years. In the world class deposits (300 tons $\mathrm{Au}$ dan $>5$ Million tons $\mathrm{Cu}$ ) generally formed under 5 million years ago (5-2.5 Ma) hosted in short multiple nested intrusion around $300-860$ thousands years as formed in Batuhijau, Grasberg, and Tujuhbukit (Garwin, 2002; Idrus et al, 2009; Maryono et al., 2012; Harrison et al., 2018).

At the eastern Sunda, porphyry deposits commonly hosted in $2 \mathrm{~km}$ of batholith diametre, with the intrusion type of tonalitic and quatz diorites. Approximately have diamtre around $<1.2 \mathrm{~km}$ atau $<0.62 \mathrm{~km}^{2}$ (Maryono et al., 2018). The type and size of intrusive appearance are influenced by the 
erosional level which influences at each region. The mineralization districts was always occupying at volcanic lithology (volcanic, pyroclastics, diatrem) which are also associated with large dioritic intrusion bodies and intrusion below the surface (Figure 2). In some places, it is found a stretch of Miocene-age coral limestone such as in the Trenggalek and Merubetiri regions, which indicates that volcanism has formed as island landform with some distal parts occurs below sea water. Increasingly to the east, as in Lombok, Sumbawa, limestone is only seen locally near the beach which indicates more dominant volcanism is present on the mainland.

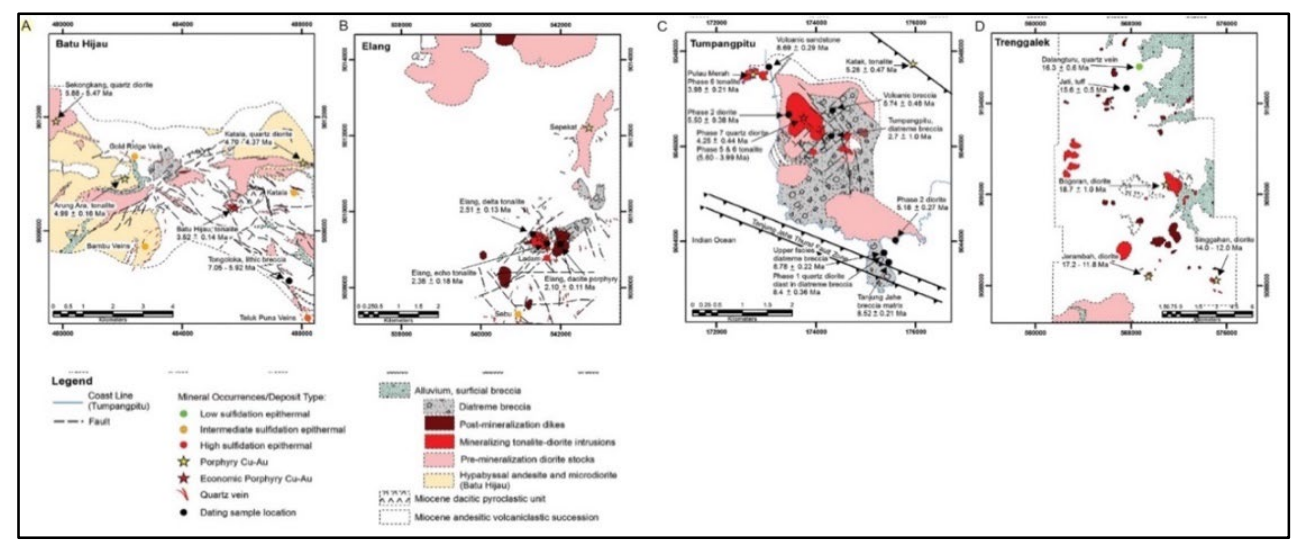

Fig. 2. Lithology characters of mineralization district in Eastern Sunda belt. (Maryono et al., 2018).

Basement / basement rocks of porphyry deposits in Eastern Sunda are dominated by Miocene volcaniclastic age which is dominated by lava and pyroclastic strata which in some places are intruded to form skarn processes such as in Batuhijau (Idrus et al., 2009). In the Java sector, there are turbiditic sedimentary rocks, such as in Tujuhbukit (Tumpangpitu) which are likely to extend below the surface with Middle Miocene age (20.67 - 16.68 Million) and partly breaking trough by the intrusion that carriers mineralized around 5M (Harrison) et al., 2018). In the eastern region, the presence of bedrock (pre-volcanism) has not yet been found which breaks through or even exposed on the surface. This indicates that there are differences in the crust beneath the surface, as in the Selogiri area found metamorphic rocks on the surface (Sutarto, 2016), while increasingly to the East as in Merubetiri it has not yet been found. So that there may be differences in basement characters between the Islands of Java and Nusa Tenggara, not much affect magmatism and hydrothermal in Eastern Sunda.

The Sunda-Banda volcanism arch has evolved for a long time, and developed parallel to the Tertiary and Quaternary paths. The Tertiary volcanism route runs along the southern mountains from Sumatra to Nusa Tenggara, and is generally in Oligocene-Miocene age (Katili, 1971), but there is magmaism in the Pliocene-Pleistocene spreading in the Java region to the east (Maryono et al., 2018). Volcanism in the Sunda-Banda arc is generally formed as volcanism of the force arch, middle arc and back arc, as is generally the volcanism that formed in the subduction path (Tatsumi and Stern, 2006). In the eastern part of the Sunda Belt, Quaternary volcanism is seen as having a path with a centralized pattern, and several forming Caldera systems such as Ijen, Batur, Bratan and 
Rinjani. In the Tertiary rock complex, increasingly to the east the Tertiary rocks limited and some were followed by Plio-Pleistocene magmatism such as the Tujuh Bukit, Batu Hijau, Elang (Garwin, 2012; Harrison et al., 2018), and possibly up to the Holocene like Hu'u (Mount Puma) that shows the presence of geothermal manifestations on the surface (Sundhoro et al., 2005).

Physiography of the Eastern Sunda shows two main complexes namely igneous rock formation and volcanoes on the south side, it followed by the alignment of volcanoes on its northern side with relatively close proximity (Figure 3). The characters of magmatism and volcanism in Tertiary, are likely similar to those formed today. The character of volcanism can be used as a reference pattern of eruption and formation of rocks on the surface, and possibly under the surface such as intrusion or batolite.
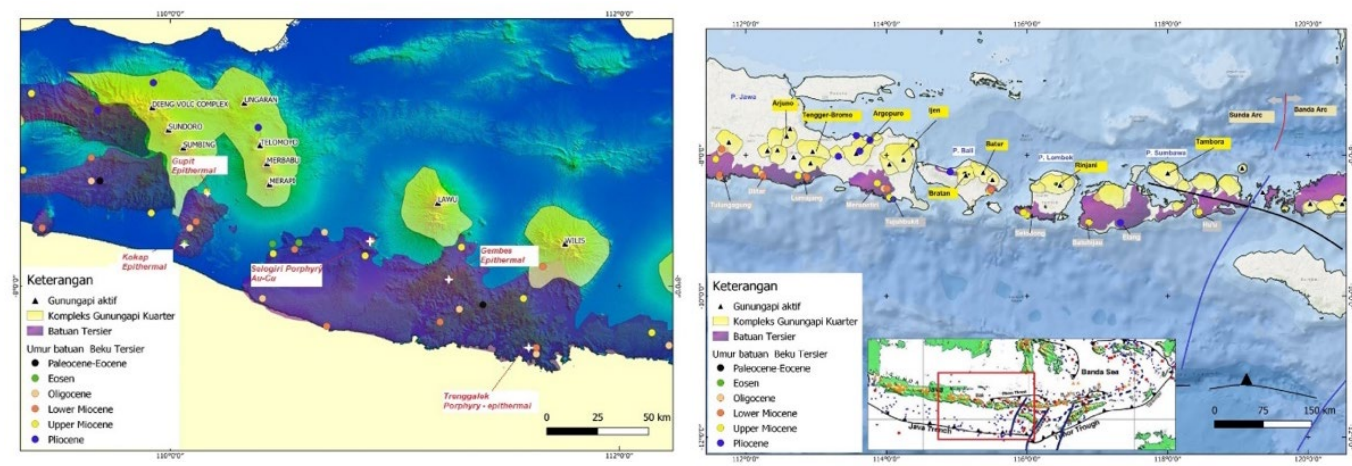

Fig. 3. Spatial relationship of active volcanism and ancient volcanism in Eastern Sunda. The position of the magmatism path at the Southern Mountains (bluish purple) in the southern region, and the position of the active Quaternary volcano (yellow) on its northern side. The boundary between Eastern Sunda and Banda is

Flores Island, with its physiographic character dominated by the Quaternary Volcano in the south.

The character of volcanism is a major factor in the formation of physiography and evolution of lithology which is in its complex. The concept of present is the key to past is well used in understanding the geological character of the Tertiary mountains on the Eastern Sunda track. The characteristics of Quaternary volcanism in active volcanic complexes today generally have caldera form, both single ones (such as Tambora and Rinjani) or those that have evolved 2 caldera (Bromo, Ijen, Batur), which always form the center of eruption at the center or on the caldera wall. The caldera complex of Eastern Java to Bali is around $7-16 \mathrm{~km}$, while on the islands of Lombok and Sumbawa around 6-7 km. The evolution of Quaternary volcanoes on the East Sunda path shows the evolution of morphology and magmatism that looks increasingly young to the west. This is also the case with Tertiary igneous rocks pathways (Maryono et al., 2018).

The product of near-surface volcanism in the Tertiary mineralization system in the Sunda path is the presence of diatrem or phreatomagmatics. Diatrem breccias are always formed in porphyry deposits in Sunda, as a post intrusion process (Maryono et al., 2018), which can develop into high sulfidation epithermal deposits such as in Tumpangpitu or as alteration feeders to form litocaps such as Batuhijau, Elang and Hu'u. On the other hand, the diatrem process serves as the beginning of the process of porphyry mineralization as a control of meteoric water depletion and sulfidation processes 
(Wilkinson, 2018). The presence of diatrem breccias, also called phreatomagmatic breccias, is very important in porphyry in Eastern Sunda, but it still leaves questions about the genetic and the relative time of formation.

Phreatomagmatic breccias are generally a process after mineralization which is proven from the position and fragmentation of breccias that are seen cutting through mineralized intrusion bodies such as those found in Eagle, Rinti, Batu Hijau, Selodong, Brambang, Tumpangpitu, Binglis, Trenggalek, and Selogiri (Maryono et al 2018). The amount of diatrem formed varies from $0.15 \mathrm{~km}^{2}$ in the Brambang area to $6.8 \mathrm{~km}^{2}$ in the Tumpangpitu area, which generally forms an inverted cone. The age of diatrem breccia is estimated to be younger than intrusion of around $2.7 \mathrm{Ma}$ in Tumpangpitu (Harrison et al., 2018) or 2.1 Ma in dacite that covering the diatrem in the Elang Deposit (Maryono et al., 2018).

The main problem in the Tertiary Belt until the beginning of the Quarter is the presence of a superimposed volcanism system, which is a repetition of a volcanic system at one relatively similar place at different geological periods, as formed in the Southern Mountains of Java (Bronto, 2006). In the Tertiary mineralization district, complexes of igneous rock are found with relatively diverse ages with very long life differences of age, such as the Batu Hijau deposit (table 2). In the evolution of porphyry magmatism in Indonesia, it is also seen that there is a multi-intrusion process over a short period of time (nested intrusion), which is $<1$ million years, as in the Batuhijau, Grasberg, and Tumpangpitu deposits (Maryono et al., 2018). This is in line with the process that occurs in the Quaternary, so that this process can be analogical to Tertiary conditions, where the evolution of volcanism and hydrothermal is strongly associated even though there is no detailed research related to it

Table 2. The intrusion geochronology of Batu Hijau District and the extent of its present (Garwin, 2012)

\begin{tabular}{|l|c|c|l|}
\hline \multicolumn{1}{|c|}{ Intrusion } & Age (Ma) & Area $\mathbf{( k m}^{2}$ ) & \multicolumn{1}{c|}{ Texture } \\
\hline Andesite Complex & $15-6,9$ & $>15$ & Porphyritic, massive \\
\hline $\begin{array}{l}\text { Quartz Diorite (QD1) } \\
\text { Sekongkang }\end{array}$ & 5,9 & 2,5 & Equigranular \\
\hline $\begin{array}{l}\text { Quartz diorite (QD2) } \\
\text { Santong }\end{array}$ & $>5.0$ & 1,5 & $\begin{array}{l}\text { Equigranular, } \\
\text { subporfiritic }\end{array}$ \\
\hline Tonalit Katala - Ara & $5,0-4,7$ & 0,3 & Porphyritic - allitic \\
\hline $\begin{array}{l}\text { Quartz diorite (QD3) } \\
\text { Batu Hijau - Katala }\end{array}$ & $4,4-3,8$ & 3 & Equigranular \\
\hline $\begin{array}{l}\text { Batu Hijau Tonalite } \\
\text { Complex }\end{array}$ & 3,7 & 0.1 & Porphyritic - aplytic \\
\hline $\begin{array}{l}\text { Diatrem and Andesite } \\
\text { Intrusion }\end{array}$ & $<3,7 ?$ & $<0,1$ & $\begin{array}{l}\text { Porphyritic, aplytic, } \\
\text { afanitic }\end{array}$ \\
\hline
\end{tabular}

The time span of volcanic caldera development is relatively short, which is around $<0.3$ million years, as formed in the Eastern Sunda region, as in the Bromo, Ijen and Batur Caldera have formed 2 caldera walls in a period of 22,000-120,000 years followed by the formation of hummock or single volcanic body (crown) on the area within the caldera. In addition, the volcanic complex also forms side eruptions, which can develop into large volcanic bodies with their own volcanic systems such 
as Mt. Sembalun as part of the old Rinjani (Sundhoro et al., 2000). In relation to hydrothermal evolution, it can be seen that in each Quaternary volcanic complex there are geothermal manifestations both in very acidic conditions at the center of the eruption such as the Ijen or in the weak zone forming geothermal conditions such as Sembalun and several other mountains.

Table 2.2. Summary of character and lifetime of quarterly volcanoes in Eastern Sunda (compilation from Sujanto et al., 1988; Sutawidjaja et al., 1992; Zaennudin et al., 1994; Sundhoro et al., 2000; Kartadinata et al., 2008; Rachmat et al., 2008) al., 2016; Geiger et al., 2018)

\begin{tabular}{|c|c|c|c|c|c|c|c|}
\hline No & $\begin{array}{c}\text { Active } \\
\text { Volcanic } \\
\text { Complex }\end{array}$ & Type & $\begin{array}{c}\text { Diamet } \\
\text { er of } \\
\text { Caldera } \\
\text { Crater }\end{array}$ & $\begin{array}{c}\text { Caldera } \\
\text { Event }\end{array}$ & $\begin{array}{c}\text { The } \\
\text { Oldest } \\
\text { Radiom } \\
\text { etric } \\
\text { Age }\end{array}$ & $\begin{array}{c}\text { The } \\
\text { Youngest } \\
\text { Radiomet } \\
\text { ric Age }\end{array}$ & Remarks \\
\hline \multirow[t]{3}{*}{1} & $\begin{array}{l}\text { Bromo } \\
\text { Tengger }\end{array}$ & $\begin{array}{c}\text { Calder } \\
\text { a }\end{array}$ & $\begin{array}{c}7-7,6 \\
\mathrm{~km}\end{array}$ & & $\begin{array}{c}>265.00 \\
0\end{array}$ & 360 & $\begin{array}{l}\text { Forms } 3 \text { dunes in } \\
\text { the caldera at this } \\
\text { time, and } \\
\text { produces } \\
\text { pyroclastic flow } \\
\text { (very large } \\
\text { ignimbrite } \\
\text { towards the } \\
\text { north-east) }\end{array}$ \\
\hline & & & & $\begin{array}{c}\text { Ngadisari } \\
\text { Caldera }\end{array}$ & 152,000 & & \\
\hline & & & & $\begin{array}{l}\text { Lautan } \\
\text { Pasir } \\
\text { Caldera }\end{array}$ & 33,000 & & \\
\hline 2 & Ijen & $\begin{array}{c}\text { Calder } \\
\text { a }\end{array}$ & $\begin{array}{c}14- \\
15,9 \mathrm{~km}\end{array}$ & $\begin{array}{c}\text { Oldest } \\
\text { Caldera and } \\
\text { Youngest } \\
\text { Caldera }\end{array}$ & 294,000 & 2,590 & $\begin{array}{l}\text { Forms around } 11 \\
\text { humocks in the } \\
\text { caldera, } \\
\text { including } 1 \\
\text { Hummock with } \\
\text { sulfur-rich } \\
\text { geothermal } \\
\text { active craters } \\
\text { (Ijen) }\end{array}$ \\
\hline \multirow[t]{3}{*}{3} & Batur & $\begin{array}{c}\text { Calder } \\
\text { a }\end{array}$ & $\begin{array}{c}9,9-13 \\
\mathrm{~km}\end{array}$ & & $\begin{array}{c}>500.00 \\
0\end{array}$ & & $\begin{array}{l}\text { Formed } 3 \text { new } \\
\text { strobolian } \\
\text { eruption centers } \\
\text { (Batur } 1,2,3 \text { ), and } \\
\text { around } 3 \\
\text { Hummocks }\end{array}$ \\
\hline & & & & Caldera 1 & 29,300 & & \\
\hline & & & & Caldera 2 & 5,000 & & \\
\hline
\end{tabular}




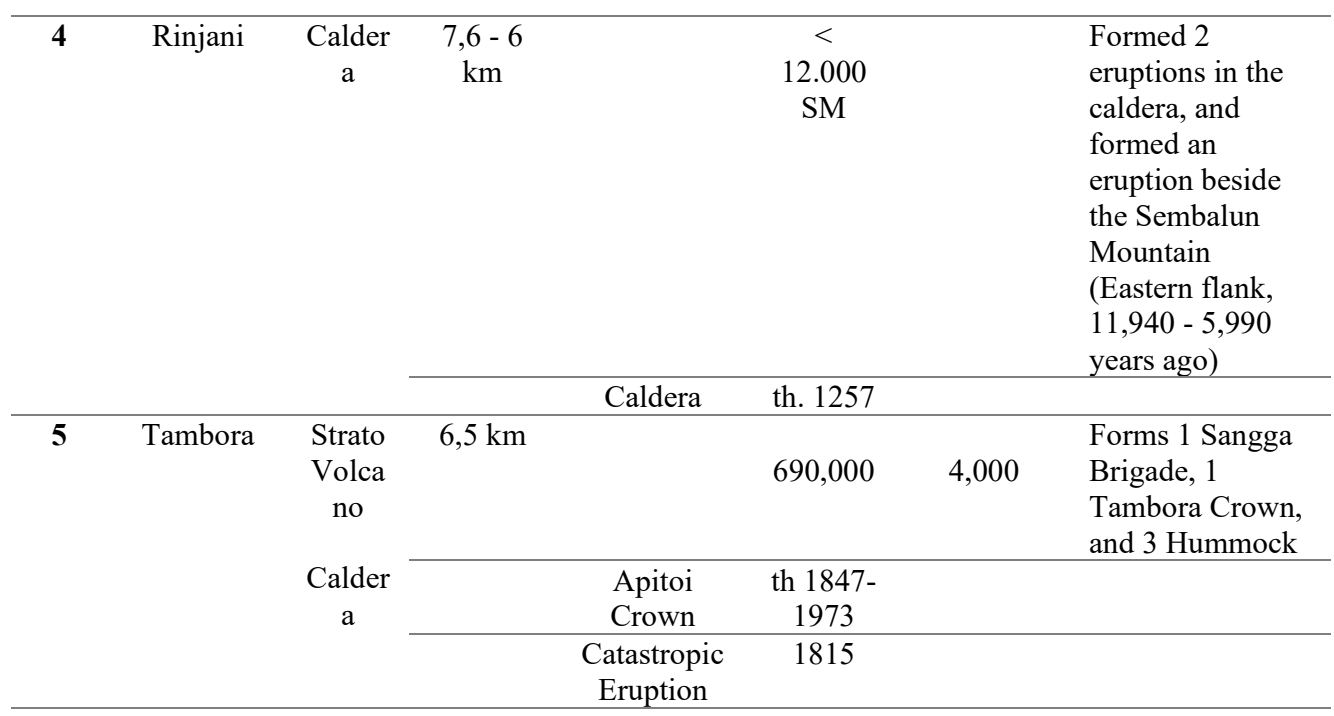

\section{Type of volcano and hydrothermal occurences}

The character of the volcanism system in Indonesia, generally forming a stratovolcano for example at the Tambora and Batur volcano which then develops into a single caldera or caldera 23 times followed by a new eruption center with magmatism becoming basaltic or dasitik. Some volcanoes issuing many phreatomagmatic eruptions such as Bromo, or followed by an eruption with acid geothermal craters such as Ijen. The volcanic complex in eastern Sunda can be associated with other strato mountains such as Bromo-Semeru, Batur-Agung, Rinjani-Sembalun, or also associate to form a cylindrical cone at its distal like Tambora (Kartadinata et al., 2008) dan Lamongan (Zaennudin et al., 1994). That's volcano form as composite volcano and caldera type. The composite which characterized by relatively large, long-lived constructional volcanic edifice, comprising lava and volcaniclastic products erupted from one or more vents, and their recycled equivalents. The composite volcano have several morphology type such as simple cone, shieldlike, compounds, twins, cluster, collape-scarred (Davidson \& Silva, 1999 in Sigurdsson et al., 2015). The caldera system are large volcanic depressions (5-75 $\mathrm{km}$ in diametre), more or less circular in form, the diameter of which is many times greater than that of included vents. Formation of calderas, by some form of roof collapse over an underlying shallow magma reservoir, is now widely recognized as accompanying most eruptions that involve magmatic volumes greater than a few cubic kilometers (Lipman, 1999 in Sigurdsson et al., 2015)). Most of Caldera type can form polygenetic volcanoes that's kill the hydrothermal system such as Toba complex, but in otherside can create the hydrothermal - mineralization activity that's happen in both recent volcanic system (Dieng, Bromo) and ancient volcanic system such as Yanacocha complex, Batu Hijau complex, (Lippman, 1999; Teal dan Benavides, 2010)

Setijadji (2010) says the geothermal system (in ancient time, called hydrothermal) of Quarternary volcano are to be placed at very near to active vent, such as such as the Kahara-Telaga 
Bodas (a vapor-type geothermal system) which is located just about $5 \mathrm{~km}$ of the vent of presently active Galunggung volcano. The majority of large geothermal fields are concentrated within Upper Neogene to Early Quaternary caldera remnants, in which many Pleistocene volcanic edifices (mostly are monogenic) were emplaced. The ages of geothermal systems are Quaternary should be around 0.2-0.5 Ma, were mainly formed during the Upper Pleistocene. So, it can be said that the hydrothermal system was formed after the formation of composites or caldera type volcano in less than $1 \mathrm{Ma}$. On the other hand, we know that the mineralization complex is occurred in long range of geologic ages, example 5-15 Ma. The problems is we don't know how long the magma can be life in subsurface and how much times the magma "born" and differentiates. Some magma can storage in subsurfare until $0.5-1.5 \mathrm{Ma}$ until crystalized in deep or released to surface become lava. Author believed, hypotetically, the concept of hydrothermal must be including the meteoric water system in surface. The meteoric water as surficial process needs the good and large aquifer, that's probable formed after large eruption periods and makes pyroclastics layer ini inner caldera facies. So, the hydrothermal system controlled by amount of circulating water and depth - size of magma storage in subvolcanic or batholithic system. The distance of circulate water to form geothermal or hydrothermal system can spread until 5-10 km from the heat source or magma (figure 4) (Hedenquist et al., 1998; Abiyudo et al., 2016), but still in central facies of caldera or volcanoes complex.

From those facts, its probably the controls of mineralization are depending on magma or plutons type and volcanism type) (figure 5). The plutons, silicate, act as main system of mineralization that's comprise of metal and fluids, and source of heat. The volcanism, act as the architect of geologic setting, including evolution of morphology and geologic controls. The finalization of both control is "the water rules" or hydrothermals system, that's formed by a combination of dominance of meteoric water from surface and magmatic water from depth 


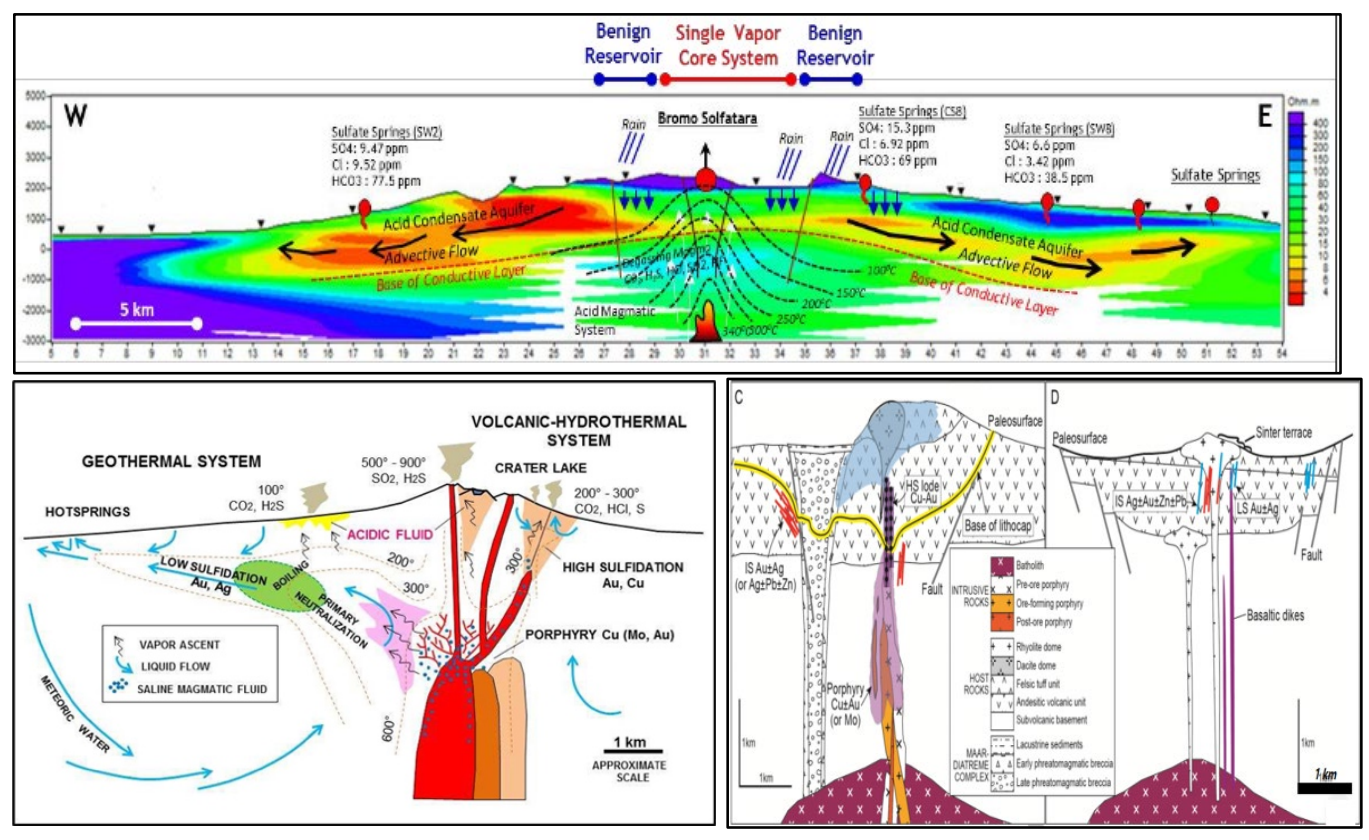

Fig. 4. Schematic model of meteoric-magmatic and temperatur of circulated fluids. (a) active geothermal field in Bromo Caldera, (Abiyudo et al., 2016), (b). volcanic-hydrothermal conceptual model (Hedenquist et al., 1998), (c-d) geological model of porphyry related to epithermal (Sillitoe, 2010; Wang et al., 2019).

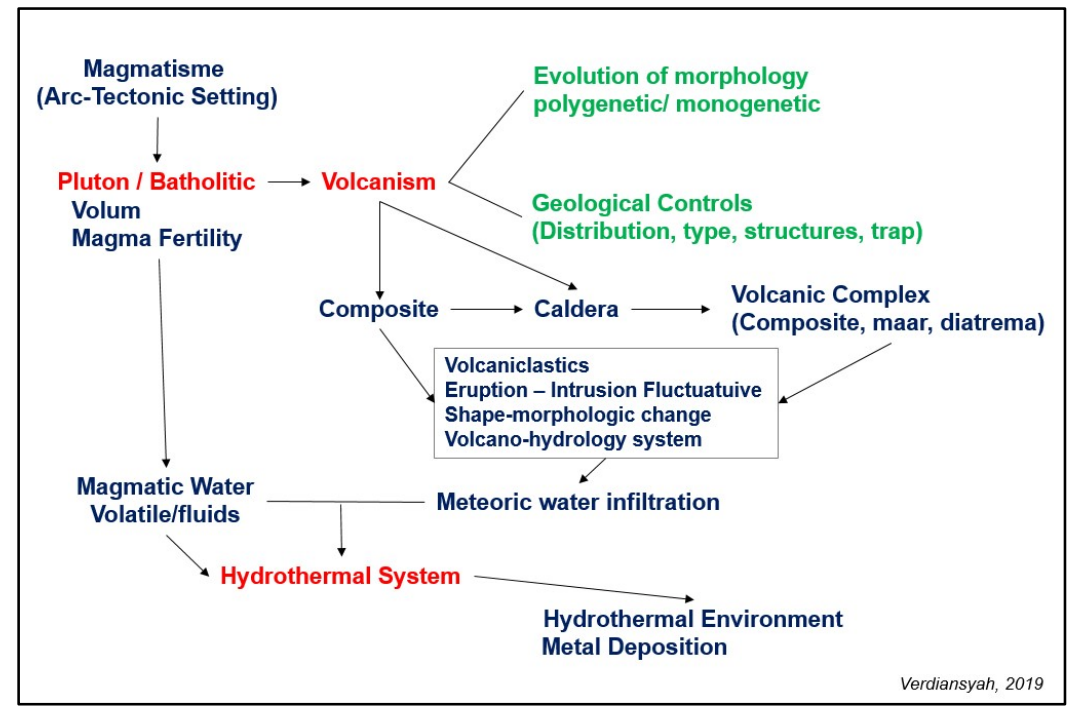

Figure 5. Hypotetically concept of volcanosetting and hydrothermal system. 
If you look into the history of the discovery of deposits in Indonesia over the last 25 year, it can be seen that many influential factors, such as the presence of the concept of exploration, the increased need for commodities, and politics (Van Leeuwen, 2018). Foccused on the concept, there is no clear geological parameters which can be used as a role model. Some of the basic concepts was missed such as the volcanic facies that emplaced by mineralization. The volcanic facies is simple concept that's based on lithological characters, to revealed the occurences of mineralization. Bogie \& Mackenzie (1998) divide the general stratovolcano volcanic in to four facies, such as central (intrusive, silicious dome, aglomerate, vent breccia), proximal (interlayer of lava and breccia-lapilli size pyroclastics), medial (tuff, stratified piroclastics, lahar), and distal (lacustrine siltstone, interbedded sand - tuff).

If we look carefully, dominantly all of metal deposits in Sunda was laying on complex of lithological unit such as pyroclastics, coheren lava, and some intrusive. It provides a simple understanding, that mineralization is only occur in the central and proximal facies. Although many researchers say it can occur in distal facies such as low sulfidation epithermal (White \& Hedenquist, 1990; Hedenquist et al., 2000), but the reality is not like that. This is due to the fact that the facies concept is not yet be distinguished as a single volcanic system, complex systems, and hydrothermal circulation systems. The epithermal system or some called vein mineralization, dominantly hosted in central to proximal facies that's characterized by interlayered of andesitic lava, tuff and some basaltic dike such as Pongkor, Cikotok, Kerta, Cibaliung in Western Java, host in andesitic lava field in Kokap, Bagelen, and Menoreh (Kulon Progo area) and in Trenggalek district, also in Pangulir, Sumbawa. Even more so for the high sulfidation type, almost occurs in dome complex and diatrem as central facies.

For example, the clear volcanic facies analysis was done by Hartono (2014) in Selogiri area. The volcanic system was called Caldera of Gadjah Mungkur, shows the central facies characterized by andesite intrusive, diorit, and some lava. The mineralization of porphyry and some associated like epithermal, was laying on this central facies (Figure 6). So, its clear the mineralization is occurs in central facies. For more volcanosetting parameters still needs further research, hipotetically it's controlled by magma generation and differentiation, generation of volcano, and timing of tectonic in this area. In other area, some research was conduct in desktop study analysis and found some linkage between volcanosetting and emplacement of mineralization, such as in Kulon Progo Mountain, Merubetiri -Tujuh Bukit Complex, and East Sumbawa Complex.

The Kulon Progo mountain (figure 7) is an example for Composite complex volcano, that's possibly form 4 paleovolcano complex (Crown-Brigade) such as Ijo Complex, Gadjah Complex, Menoreh Complex (Van Bemmelen, 1949; Harjanto, 2011; Widagdo et al., 2018) and hipotetically older one as Loano Complex (Verdiansyah, 2019). In this area there is evidence of economically deposits but still occurs some mineralization type such as epithermal vein in Kokap (Pramumijoyo et al., 2017), epithermal related to dacitic dome (Prasetyo et al., 2017), high sulfidation epithermal in Gupit (Idrus et al., 2013) and possibly of porphyry copper in sambisari (Verdiansyah, 2019). That's all mineralization occurs in central facies of each volcanosetting area or for regionaally central of Brigade or Crown. Some setting that's controlled this area is the paleo water circulation, or hydrovolcano setting of Kulon Progo area is not large, because of more three-quarter volcano body was subamrine condition. That's proved by the occurences of carbonates in top of volcano. This condition creates minor hydrothermal circulation in some area, but still possibly if mineralization controlled by deep magmatic fluid source, if any. 
The Merubetiri Complex (figure 8a) is an example of Caldera Complex that's arise closely an makes some superimposed volcano with long periods time, from Oligocene to Pleistocene (Setijadji et al., 2006; Harrison et al., 2018) but commonly in Miocene age. This complex volcano and magmatism in Merubetiri setting makes complex of lithological overlapping and also the confusing mineralization geochronology.

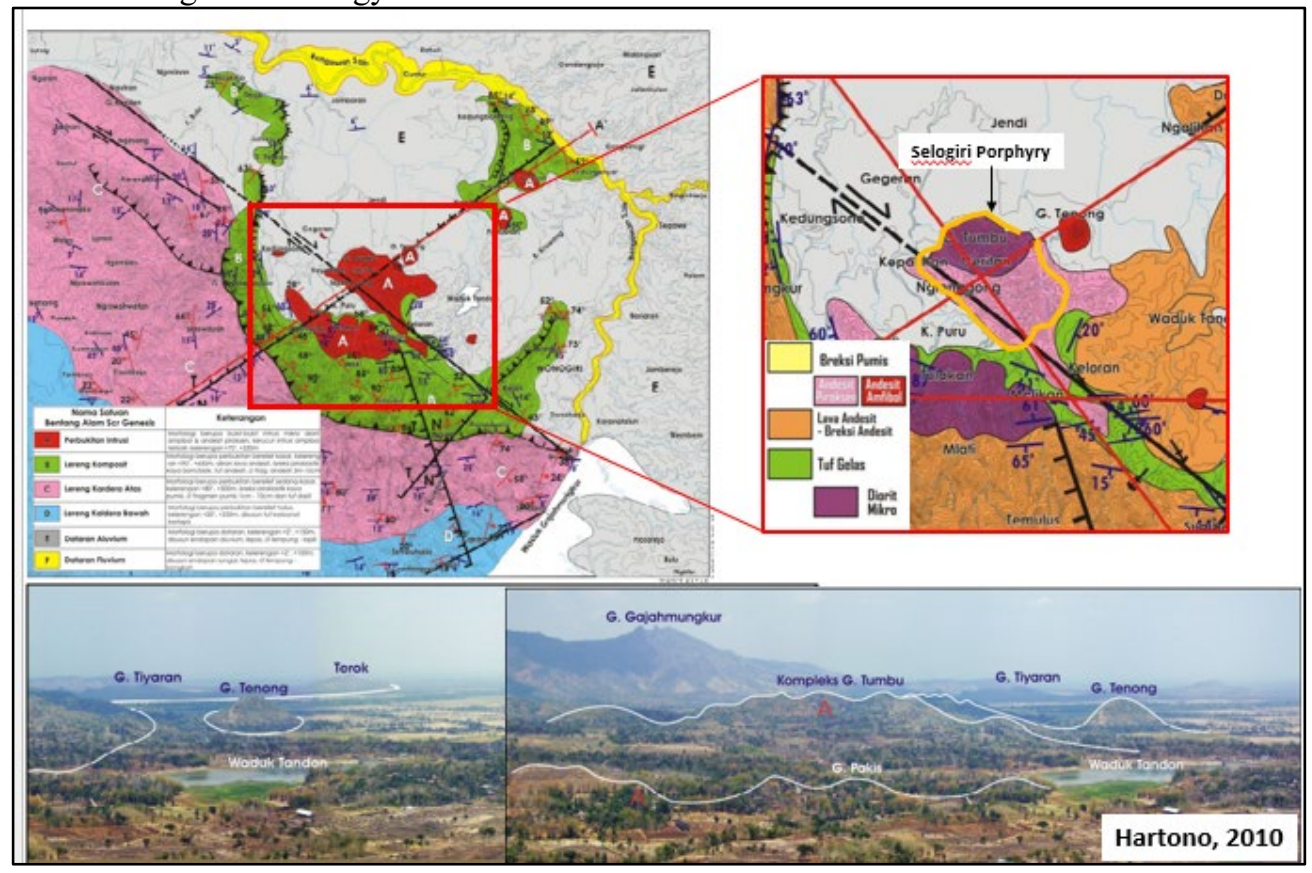

Fig. 6. Correlation between volcanic facies and mineralization in Selogiri Porphyry Deposits, Gadjah Mungkur, Central Java (Hartono, 2010, 2014; Muthi et al., 2012; Sutarto et al., 2016).

Hipotetically there is $5-6$ volcano complex that's creates caldera system in this area, with some eruption center inside it. These volcano generation was not clearly understood until know, because no specific research done in this area. But from this dekstop study, hipotetically the mineralization occurs in central facies of caldera of central composite volcano, such as Silo area as epithermal and intrusion related, and Salakan - Tumpang Pitu at Tujuh Bukit Complex as high sulfidation epithermal and porphyry $\mathrm{Cu}-\mathrm{Au}$ mineralization that's laying on diatrem and intrusive rock as central facies of Plio-pleistocene volcano in Southeast part of Merubetiri. The other possibly setting is the generation or growth of volcanoes system from submarine to become the subaerial setting, include the explosive characters and remnain landform, that's controlling the hydrothermal system in this area.

The East Sumbawa Complex (figure $8 b$ ) is an area that's created by separate Caldera system, at least 4 in this desktop study, that's connected with smaller volcanic group in between. Because there is no previous research for this volcano setting, so I prefer to use the subdistrict names as 
volcano complex names. The volcanic complex consists of Dompu Complex, Campa Complex, Daha Complex, and Lambitu Complex. Some volcanic complex interpreted has a caldera system such as Dompu complex and Daha complex. The volcanic complex more east-west orientation and some occur in the southern area such as Daha Complex, and followed by the smaller volcanic group with east-west trends create the Bima, Cempi, and Mada volcanic group. All volcano complex are interpreted have one to two central facies, that creates a caldera system and following with few central volcanic eruptions as a single volcanic system. If the number of central eruptions increases then it is interpreted more active and complex the volcanic system and can be forming the great hydrothermal system. In this desktop study, we focus on Daha, Campa, and the east side of the Dompu Complex. Regionally, the lithology of rocks in this area consists of Tertiary volcanic rocks, such as andesite lava, pyroclastics, and some sediments (Sudradjat et al., 1998). But in the southern part, like Daha, have an active geothermal system that allows the formation of a quarterly system (Sundhoro et al., 2005; Van Leeuwen, 2018). Therefore, there is no published age dating or geochronology data yet, but based on the morphology analysis there are bright differences between the active volcanic system in the northern part and ancient or paleovolcano system is the south area. The mineralization occur as epithermal in Rango or Lepadi (Herman, 2008) and complex mineralization of epithermal and porphyry at Hu'u (Van Leeuwen, 2018) in central facies of Daha Caldera.

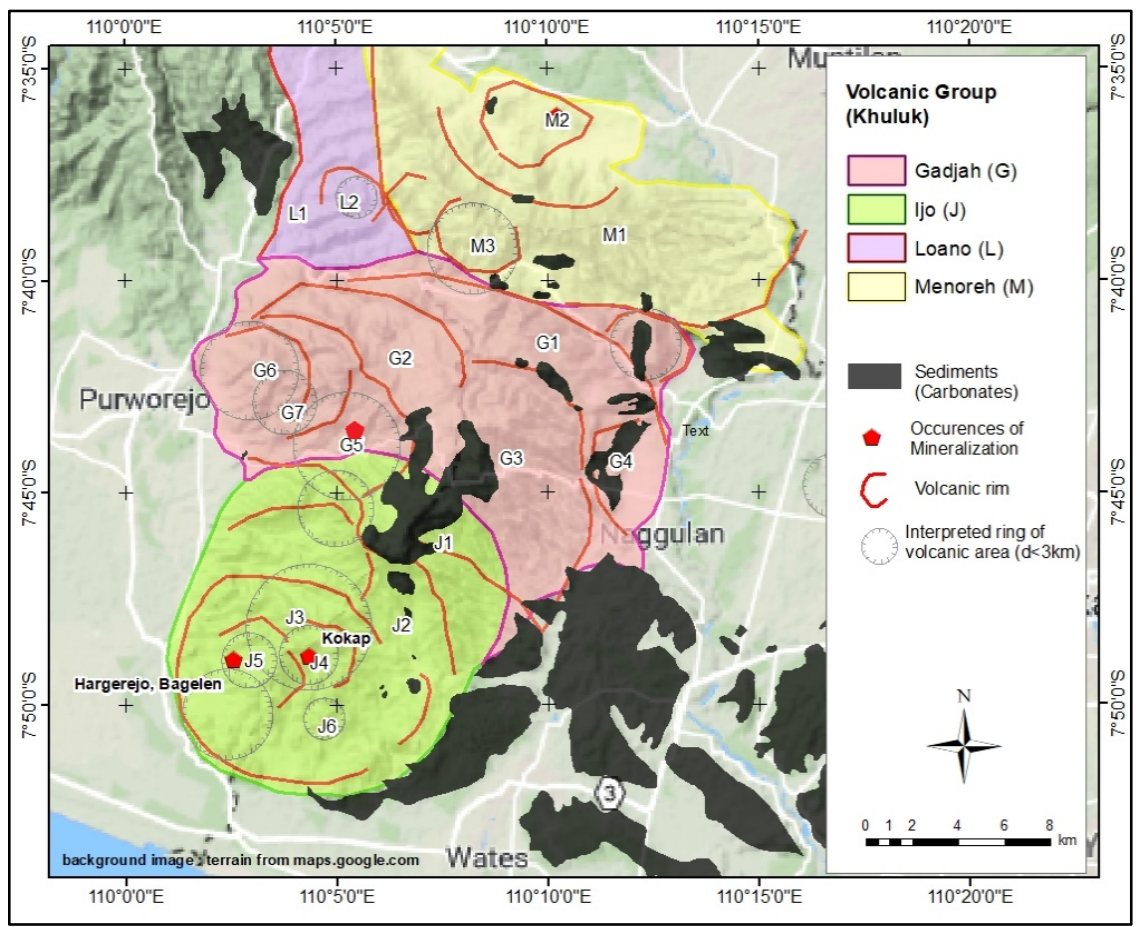


Figure 7. Volcanic group oof Kulon Progo Complex, that shows position of mineralization occurences in central facies (red pentagonal in grey circle) (Verdiansyah, 2019). The Kulon Progo is Complex of Northsouth oriented Composite stratovolcano. The occurences of sediments (carbonates) in Kulon Progo area give concluion of submarine condition in more three-quarter part of volcanoes body.
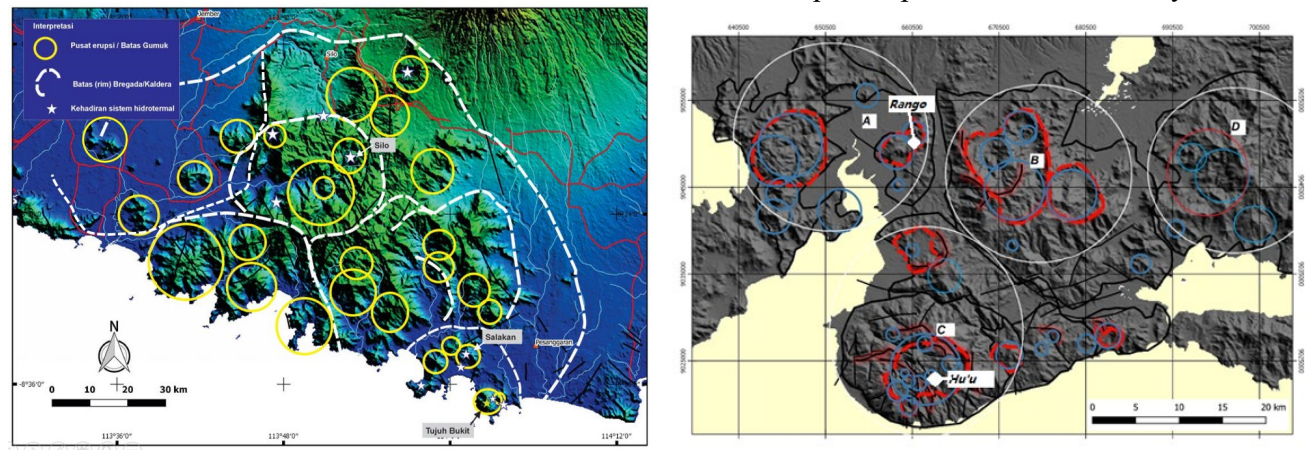

Fig. 8. The interpretation of the volcanic system in Complex volcano or Caldera system. (a) Merubetiri complex, shows closed-caldera or large composite volcano system, with long periods of magmatism and volcanism. (b) opened-caldera system in East Sumbawa, that's makes 4 separates caldera system but still connected with volcano group in between. The mineralization occurs in their own central caldera facies and specify in central of eruption, such as Hu'u prospect.

\section{Conclusion}

The simply volcanosetting concept, the volcanic facies, can be used to facilitate the discovery of deposits as a limitation of exploration area. It's an pilot parameter to create the greater volcanosetting concept. Other setting still needed further development are the volcano-chronology, volcanic landform evolution, volcano-tectonic, hydrothermal circulation and timing of mineral deposition.

\section{References}

[1] Abiyudo, R., Hadi, J., Cumming, W. dan Marini, L. (2016) "Conceptual model assessment of a Vapor Core Geothermal System for Exploration; Mt . Bromo Case Study,” (August).

[2] Becerril, L., Galindo, I., Gudmundsson, A. dan Morales, J. M. (2013) "Depth of origin of magma in eruptions," Scientific Reports, 3, hal. 1-6. doi: 10.1038/srep02762.

[3] Van Bemmelen, R. W. (1949) The Geology of Indonesia, vol. IA, General Geology of Indonesia and Adjacent Archipelagoes. 2 ed. The Hague. Netherlands.

[4] Bogie, I. dan Mackenzie, K. M. (1998) The application of a volcanic facies model to an andesitic stratovolcano hosted geothermal system at Wayang Windu, Java, Indonesia, 20th New Zealand Geothermal Workshop.

[5] Bronto, S. (2006) "Fasies gunung api dan aplikasinya," Jurnal Geologi Indonesia, 1(2), hal. 59-71.

[6] Garwin, S. (2002) "The geologic setting of intrusion-related hydrothermal systems near the Batu Hijau porphyry coppergold deposit, Sumbawa, Indonesia Publ., 9, .," Soc. Econ. Geol, hal. 333-366.

[7] Garwin, S. (2012) "District-scale Expression of Intrusion-related Hydrothermal Systems near the Batu Hijau Porphyry Copper-Gold Deposit, Sumbawa, Indonesia,” in MGEI Annual Meeting 2012. 
[8] Geiger, H., Troll, V. R., Jolis, E. M., Deegan, F. M., Harris, C., Hilton, D. R. dan Freda, C. (2018) "Multi-level magma plumbing at Agung and Batur volcanoes increases risk of hazardous eruptions," Scientific Reports. Springer US, (June), hal. 1-14. doi: 10.1038/s41598-018-28125-2.

[9] Hammarstrom, J.M., Bookstrom, A. A., Dicken, C. L., Drenth, B. J., Ludington, S., Robinson, G.R., J., Setiabudi, B. T., Sukserm, W., Sunuhadi, D. N., Wah, A. Y. S. dan Zientek, M. L. (2013) Porphyry copper assessment of Southeast Asia and Melanesia: U.S. Geological Survey Scientific Investigations Report 2010 5090-D. Diedit oleh Michael L. Zientek, Jane M. Hammarstrom, dan K. M. Johnson. U.S. Geological Survey, Reston, Virginia: 2013 This. Tersedia pada: http://pubs.usgs.gov/sir/2010/5090/d/.

[10] Harijoko, A., Uruma, R., Wibowo, H. E., Setijadji, L. D., Imai, A. dan Watanabe, K. (2010) "LongTerm Volcanic Evolution Surrounding Dieng Geothermal Area, Indonesia," in Proceedings World Geothermal Congress. Bali, Indonesia, hal. 25-29.

[11] Harijoko, A., Uruma, R., Wibowo, H. E., Setijadji, L. D., Imai, A., Yonezu, K. dan Watanabe, K. (2016) "Geochronology and magmatic evolution of the Dieng Volcanic Complex, Central Java, Indonesia and their relationships to geothermal resources," Journal of Volcanology and Geothermal Research. Elsevier B.V., 310, hal. 209-224. doi: 10.1016/j.jvolgeores.2015.12.010.

[12] Harjanto, A. (2011) "Vulkanostratigrafi Di Daerah Kulon Progo Dan Sekitarnya, Daerah Istimewa Yogyakarta,” Jurnal Ilmiah MTG, 4(8), hal. 1-18.

[13] Harjanto, A., Suparka, E., Asikin, S. dan Yuwono, Y. S. (2006) "Magmatic related to hydrothermal alteration in Kulon Progo, Central Java, Indonesia," in Kusumayudha, S. B., Sutarto, Hartono, H. G., Rao, N., Purwanto, H. S., Sakundarini, N., Danisworo, C., Limaye, S. D., dan Balderner, W. (ed.) International Interdisciplinary Conference Volcano International Gathering. Yogyakarta: Planetearth.

[14] Harrison, R. L., Maryono, A., Norris, M. S., Rohrlach, B. D., Cooke, D. R., Thompson, J. M., Creaser, R. A. dan Thiede, D. S. (2018) "Geochronology of the Tumpangpitu porphyry Au-Cu-Mo and highsulfidation epithermal Au-Ag-Cu deposit: Evidence for pre-and postmineralization diatremes in the Tujuh Bukit district, Southeast Java, Indonesia,” Economic Geology, 113(1), hal. 163-192. Tersedia pada: https://doi.org/10.5382/econgeo.2018.4547.

[15] Hartono, H. G. (2010) Peran Paleovolkanisme Dalam Tataan Produk Batuan Gunung Api Tersier di Gunung Gajahmungkur, Wonogiri, Jawa Tengah. University Padjadjaran.

[16] Hartono, H. G. (2014) “Geologi Gunung Api Purba Gajahmungkur, Wonogiri, Jawa Tengah,” MTG, 4(2).

[17] Hedenquist, J. W., Arribas, A. R. dan Gonzalez-Urien, E. (2000) "Exploration for Epithermal Gold Deposits," Society of Economic Geologists, Reviews in Economic Geology, 13, hal. 245-277.

[18] Hedenquist, J. W., Arribas, A. dan Reynolds, T. J. (1998) "Evolution of an intrusion-centered hydrothermal system: far southeast-Lepanto porphyry and epithermal $\mathrm{Cu}-\mathrm{Au}$ deposits, Philippines," Economic Geology, 93(4), hal. 373-404. doi: 10.2113/gsecongeo.93.4.373.

[19] Herman, D. zulkifli (2008) "Mineralisasi pada batuan induk batugamping di daerah Lepadi, Dompu, Nusa Tenggara Barat,” Jurnal geologi Indonesia, 3(3), hal. 175-182.

[20] Idrus, A., Kolb, J. dan Meyer, F. M. (2009) "Mineralogy, lithogeochemistry and elemental mass balance of the hydrothermal alteration associated with the Gold-rich Batu Hijau Porphyry copper deposit, sumbawa Island, Indonesia,” Resource Geology, 59(3), hal. 215-230. doi: 10.1111/j.1751-3928.2009.00092.x. 
[21] Idrus, A., Kolb, J., Meyer, F. M., Arif, J., Setyandhaka, D. dan Kepli, S. (2009) “A preliminary study on skarn-related calc-silicate rocks associated with the Batu Hijau Porphyry copper-gold deposit, Sumbawa Island, Indonesia," Resource Geology, 59(3), hal. 295-306. doi: 10.1111/j.1751-3928.2009.00097.x.

[22] Idrus, A., Warmada, I. W. dan Putri, R. I. (2013) "Mineralisasi Emas di gunung Gupit, Magelang, Jawa Tengah: Sebuah Penemuan Baru Prospek Emas Tipe Ephitermal Sulfidasi Tinggi pada Rangkaian Pegunungan Kulon Progo-Menoreh."

[23] Kartadinata, M. ., Mulyana, A. R., Kriswati, E. dan Haerani, N. (2008) "Peta Geologi Gunungapi Tambora Sumbawa, Provinsi Nusa Tenggara Barat.” Pusat Vulkanologi dan Mitigasi Bencana Geologi.

[24] Katili, J. A. (1971) "A review of the geotectonic theories and tectonic maps of Indonesia," EarthScience Reviews. Elsevier, 7(3), hal. 143-163.

[25] Maryono, A., Harrison, R. L., Cooke, D. R., Rompo, I. dan Hoschke, T. G. (2018) “Tectonics and Geology of Porphyry Cu-Au Deposits along the Eastern Sunda Magmatic Arc, Indonesia," Economic Geology, 113(1), hal. 7-38. Tersedia pada: http://dx.doi.org/10.5382/econgeo.2018.4542.

[26] Maryono, A., Setijadji, L. D., Arif, J., Harrison, R. dan Soeriaatmadja, E. (2012) "Gold, Silver and Copper Metallogeny of the Eastern Sunda Magmatic Arc Indonesia," in Proceeding of Banda and Eastern Sunda Arcs 2012 MGEI Annual Convention, hal. 26-27.

[27] Muthi, A., Basten, I. G., Suasta, I. G. M. dan Litaay, N. E. W. (2012) "Characteristics of Alteration and Mineralization at Randu Kuning - Wonogiri Project," in PROCEEDINGS OF BANDA AND EASTERN SUNDA ARCS 2012 MGEI ANNUAL CONVENTION 26-27 November 2012, Malang, East Java, Indonesia. Malang, East java, hal. 117-133.

[28] Newhall, C. G., Bronto, S., Alloway, B., Banks, N. G., Bahar, I., Del Marmol, M. A., Hadisantono, R. D., Holcomb, R. T., McGeehin, J., Miksic, J. N., Rubin, M., Sayudi, S. D., Sukhyar, R., Andreastuti, S., Tilling, R. I., Torley, R., Trimble, D. dan Wirakusumah, A. D. (2000) “10,000 Years of explosive eruptions of Merapi Volcano, Central Java: Archaeological and modern implications,” Journal of Volcanology and Geothermal Research, 100(1-4), hal. 9-50. doi: 10.1016/S0377-0273(00)00132-3.

[29] Nomikou, P., Papanikolaou, D., Alexandri, M., Sakellariou, D. dan Rousakis, G. (2013) "Submarine volcanoes along the aegean volcanic arc," Tectonophysics. Elsevier B.V., 597-598, hal. 123-146. doi: 10.1016/j.tecto.2012.10.001.

[30] Pramumijoyo, P., Idrus, A., Warmada, I. W. dan Yonezu, K. (2017) “Geology, Geochemistry and Hydrothermal Fluid Characteristics of Low Sulfidation Epithermal Deposit in the Sangon Area , Kokap , Special Region of Yogyakarta," Journal of Apllied Geology, 2(1), hal. 48-58. doi: 10.22146/jag.30...

[31] Prasetyo, L. A., Fadlin, Siswandi, Anggoro, W. T. dan Oktaviany, A. (2017) "Pre-Eliminary Study High Sulphidation Epithermal Gold And Possibility Porphyry System In The Southern Part Of Kulonprogo Dome- Hargerejo- Bagelen- Purworejo," in JCM HAGI-IAGI-IAFMI-IATMI.

[32] Rachmat, H., Rosana, M., Djumarma Wirakusumah, A. dan Abdul Jabbar, G. (2016) Petrogenesis of Rinjani Post-1257-Caldera-Forming-Eruption Lava Flows, Indonesian Journal on Geoscience. doi: 10.17014/ijog.3.2.107-126.

[33] Setijadji, L. D. (2010) "Segmented Volcanic Arc and its Association with Geothermal Fields in Java Island, Indonesia," in Proceedings World Geothermal Congress, hal. 25-29.

[34] Setijadji, L. D., Kajino, S., Imai, A. dan Watanabe, K. (2006) "Cenozoic island arc magmatism in Java Island (Sunda Arc, Indonesia): Clues on relationships between geodynamics of volcanic centers and ore mineralization,” Resource Geology, 56(3), hal. 267-292. doi: 10.1111/j.1751-3928.2006.tb00284.x. 
[35] Setijadji, L. D. dan Maryono, A. (2012) "Geology and Arc Magmatism of the Eastern Sunda Arc, Indonesia," in Proceeding of Banda and Eastern Sunda Arcs 2012 MGEI Annual Convention, hal. 26-27.

[36] Sigurdsson, H., Houghton, B., McNutt, S., Rymer, H. dan Stix, J. (2015) The encyclopedia of volcanoes. Elsevier.

[37] Sillitoe, R. H. (2010) “Porphyry Copper Systems," Economic Geology, 105, hal. 3-41.

[38] Sudradjat, A., Mangga, A. dan Suwarna, N. (1998) "Peta Geologi Regional Lembar Sumbawa, Nusa Tenggara skala 1:250.000.” Bandung: Pusat Penelitian dan Pengembangan Geologi.

[39] Sujanto, Syarifuddin, M. Z. dan Sitorus, K. (1988) "Peta Geologi Gunungapi Komplek Kaldera Ijen, JawaTimur.” Direktorat Vulkanologi Indonesia.

[40] Sundhoro, H., Bakrun, Sulaeman, B., Situmorang, T., Sumardi, E., Imanuel, M., Risdiato, D. dan Liliek, R. (2005) "Survei Panas Bumi Terpadu (Geologi, Geokimia dan Geofisika) Daerah Hu'u, Kabupaten Dompu, Provinsi Nusa Tenggara Barat," in Proceedings Kolukium Hasil Lapangan - DIM 2005, hal. 38-1 $-38-10$.

[41] Sundhoro, H., Nasution, A. dan Simanjuntak, J. (2000) "Sembalun Bumbung Geothermal Area, Lombok Island, West Nusatenggara, Indonesia: An Integrated Exploration," in Proceedings World Geothermal Congress, May 28 - June 10, 2000. Kyushu - Tohoku, Japan.

[42] Sutarto (2016) Petrology, Geochemistry And Hydrothermal Fluid Evolution Of The Randu Kuning Porphyry Cu-Au And Epithermal Au Deposits In Selogiri, Central Java, Indonesia. University of Gadjah Mada.

[43] Sutarto, Idrus, A., Harijoko, A., Setijadji, L. D., Michael, F., Sindern, S. dan Putranto, S. (2016) "Hydrothermal Alteration and Mineralization of the Randu Kuning Porphyry $\mathrm{Cu}-\mathrm{Au}$ and Intermediate Sulphidation Epithermal Au-Base Metals Deposits in Selogiri , Central Java, Indonesia,” Journal of Apllied Geology, 1(1), hal. 1-18va.

[44] Sutawidjaja, I. S., Chaniago, R. dan Kamal, S. (1992) "Peta Geologi Kaldera Batur, Bali, Indonesia." Direktorat Vulkanologi Indonesia.

[45] Tatsumi, Y. dan Stern, R. (2006) "Manufacturing Continental Crust in the Subduction Factory," Oceanography, 19(4), hal. 104-112. doi: 10.5670/oceanog.2006.09.

[46] Teal, L. dan Benavides, A. (2010) "History and geologic overview of the Yanacocha mining district, Cajamarca, Peru,” Economic Geology, 105(7), hal. 1173-1190. doi: 10.2113/econgeo.105.7.1173.

[47] Ten, V., Gottsmann, J. dan Martí, J. (2011) Caldera volcanism: analysis, modelling and response. Elsevier.

[48] Van Leeuwen, T. (2018) Twenty five More Years of Mineral Exploration and Discovery in Indonesia (1993 - 2017). Jakarta: 10 th anniversary Special Publication-Masyarakat Geologi Ekonomi Indonesia.

[49] Verdiansyah, O. (2019) “A Desktop Study to Determine Mineralization Using Lineament Density Analysis at Kulon Progo Mountains , Yogyakarta and Central Java Province , Indonesia,” Indonesian Journal of Geography, 50(1), hal. 41-52. doi: http://dx.doi.org/10.22146/ijg.37442.

[50] Verdiansyah, O. dan Hartono, H. G. (2017) "Alterasi Hidrotermal Dan Mineralisasi Logam Berharga Di Cekungan Yogyakarta: Sebuah Pemikiran dari Kehadiran Sistem Hidrotermal daerah Godean," in Seminar Nasional Fakultas Teknik Geologi Ke-3. Bandung: Universitas Padjadjaran, hal. 2.16.

[51] Wang, L., Qin, K. Z., Song, G. X. dan Li, G. M. (2019) “A review of intermediate sulfidation epithermal deposits and subclassification,” Ore Geology Reviews. Elsevier B.V., 107(February), hal. 434-456. doi: 10.1016/j.oregeorev.2019.02.023. 
[52] White, N. C. dan Hedenquist, J. W. (1990) "Epithermal Environments and Styles of Mineralization: Variations and their Causes, and Guidelines for Exploration.," in J.W. Hedenquist, N. C. W. and G. S. (Editors) (ed.) Epithermal gold mineralisation of the Circum Pacific: Geology, Geochemistry, Origin and Exploration. Journal of Geochemical Exploration, 36, hal. 445-474.

[53] Widagdo, A., Pramumijoyo, S. dan Harijoko, A. (2018) "The Morphotectono-Volcanic of MenorehGajah-Ijo Volcanic Rock In Western Side of Yogyakarta-Indonesia,” Journal of Geoscience, Engineering, Environment, and Technology, 3(3), hal. 155. doi: 10.24273/jgeet.2018.3.3.1715.

[54] Wilkinson, J. J. (2018) "Porphyry-type ore deposits origins, fertility indicators and exploration targeting."

[55] Zaennudin, A., Hadisantono, R. D., Erfan, R. D. dan Mulyana, A. R. (1994) "Peta Geologi Gununapi Bromo - Tengger, Jawa Timur.” Direktorat Vulkanologi Indonesia.

[56] Zellmer, G. F., Annen, C., Charlier, B. L. A., George, R. M. M., Turner, S. P. dan Hawkesworth, C. J. (2005) "Magma evolution and ascent at volcanic arcs: Constraining petrogenetic processes through rates and chronologies," Journal of Volcanology and Geothermal Research, 140(1-3), hal. 171-191. doi: 10.1016/j.jvolgeores.2004.07.020. 